\title{
ADHESIVE BONDED HOT DIP ZINC COATED SHEET AND TITANIUM SHEET JOINT STRENGTH - NUMERICAL ANALYSIS
}

\author{
Anna Rudawska \\ Technical University of Lublin, Department of Production Engineering \\ Nadbystrzycka Street 36, 20-618 Lublin, Poland \\ tel.: +48815381232 \\ e-mail:a.rudawska@pollub.pl
}

Hubert Dębski

Technical University of Lublin, Department of Machine Design
Nadbystrzycka Street 36, 20-618 Lublin, Poland
tel.: +48 81 5381201
e-mail: h.debski@pollub.pl

Abstract

This paper describes a numerical analysis of adhesively bonded hot dip zinc coated sheet and titanium sheet and its comparison with the results of experimental tests. The study aims at presenting a comparative analysis of numerical calculation results with the results of strength test of the joints in question. Numerical simulations are an invaluable extension of experimental tests and, moreover, prove particularly useful at joint designing and analysis stages. The calculations were conducted with ABAQUS Standard software and allowed for the destructive force value obtained in experimental tests. Strength tests were conducted on single-lap adhesive joints for given structural materials; the samples were shear-loaded. The comparison of the results of experimental tests and numerical analysis led us to observe certain inconsistencies in the destructive force values, consequently providing information on the accuracy of a numerical model when compared with the actual model.

Geometric model of the analysed single-lap adhesive joint, numerical model of the analysed single-lap adhesive joint, adhesive layer failure criterion description, visualisation of the analysed single-lap joint failure process, visualisation of adhesive joint failure stages of adhesive layer are presented.

Keywords: adhesive joint, finite elements method (FEM), adhesive joints strength

\section{Introduction}

Adhesive bonding is one of the methods of forming assembly joints. They are found in a range of applications, such as machines and devices in aircraft, machine building, automotive or building industries. Competitiveness of adhesive joining technology results from its numerous advantages, including the lightness of construction, resistance to numerous aggressive factors, no unnecessary structural changes, when joining materials or simultaneous joining and sealing $[3-5,16]$. However, it appears that it is the possibility of joining materials of different properties that favours the method among others. Frequently adhesive bonding is virtually the only alternative in the case polymer and metal adherends. Joining such materials requires knowledge on the adhered elements properties, the appropriate surface preparation method, or the selection of a type of adhesive, which would provide high adhesion with both adherends $[5,16]$.

Tests presented in this article were conducted on a single-lap shear-loaded adhesive joint. When compared to other adhesive joint types loaded in different variants, this joint is capable of carrying highest loads. Numerous researchers $[4,5]$ highlight advantages of this particular type of technology, while literature $[6,7,10,13,14]$ offers a number of analyses of different shear- 
loaded joint types. Nevertheless, due to the specific character of adhesive joints and a number of factors determining their correct designing, forming and working, it is essential to analyse such a joint particularly including the FEM numerical analysis $[4,15,16]$.

The analysed joint consisted of two materials - hot dip coated sheet and titanium sheet. The adherends are of distinct mechanical and physical properties or geometry (thickness in particular). Moreover, the materials are dissimilar in terms of adhesive properties of their surfaces, which bear significance on final joint strength.

The tests were oriented towards conducting comparative analysis of the results of both numerical and strength tests of the joint in question. The purpose of the experimental tests was to determine destructive force values in the conducted strength tests.

\section{FEM analysis in adhesive joint design}

Adhesive joint strength is one of the basic factors determining application of adhesive joints in specific operating conditions. Multiple factors influence adhesive joint strength [2-4, 7, 14] e.g. material (properties of the adhesive and the material), structural (type of load, geometry of the joint), as well as technological (surface preparation prior to joining, the hardening process applied and conditions in which it takes place). All these factors need to be considered when designing adhesive joints. However, due to the characteristics of such joints, operating conditions, the type of joined materials and the applied adhesive, each type of adhesive joint should be designed individually. Designing and creating hybrid joints composed of different materials requires special consideration in particular.

FEM numerical analysis seems to complete research at both designing and experimental tests stages $[4,9-11,12,16]$. It proves highly useful at the design stage as it may simulate the influence of different types of external loads on the joint. Adhesive joint numerical analysis enables determining stress distribution in the adhesive layer and therefore indicates structural elements, which require special attention during construction or operation [8, 9]. Furthermore, adjusting dimensions or shape of the analysed structure as well as the type and place of load is possible. FEM used in joint designing allows immediate verification of the joint as well as optimisation of the aforementioned parameters.

The numerical analysis was conducted with ABAQUS/Standard software $[1,2]$. This program allows using "special" finite elements - cohesive elements - used primarily in modelling adhesive materials (e.g. adhesives) and allowing modelling of the adhesive layer failure mechanism.

\section{Experimental and numerical analysis}

\subsection{Experimental tests}

The experimental and numerical analyses were conducted on single-lap adhesive joint specimens of shear-loaded hot dip zinc coated sheet and CP1 titanium sheet. The geometric model of the analysed joint is shown in Fig. 1.

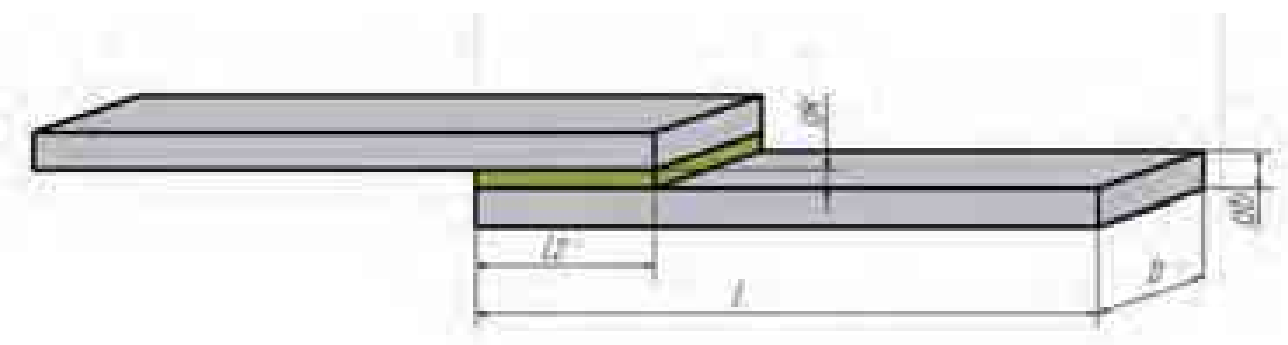

Fig. 1. Geometric model of the analysed single-lap adhesive joint [9] 
Specimens were of the following dimensions: length $1=100 \mathrm{~mm}$, width $\mathrm{b}=20 \mathrm{~mm}$, adhesive layer thickness $\mathrm{gk}=0.1 \mathrm{~mm}$, titanium sheet thickness $\mathrm{g} 1=0.4 \mathrm{~mm}$, hot dip zinc coated sheet thickness $\mathrm{g} 2=0.7 \mathrm{~mm}$ and the lap length $\mathrm{lz}=10 \mathrm{~mm}$.

Materials were bonded with Loctite 3430 two-component epoxy adhesive. Prior to adhesive joining, the surface of adherends was degreased with Loctite 7063 degreasing agent. The surface preparation process as well as adhesive joining conditions was presented in paper [11]. Strength tests were conducted on Zwick 100 materials testing machine, according to shear-loaded adhesive joints testing standards.

\subsection{Numerical analysis}

The geometric model of adhesive joints used in tests (Fig. 1) was used to build the numerical model of joints, based on a structural mesh of hexagonal solid type finite elements. For both adhesive layer and adhered sheets a very fine mesh was used in the critical areas along the edges of the lap, where large stress gradients are expected $[4,8,9,14]$. The numerical model of the joint is shown in Fig. 2.

a)

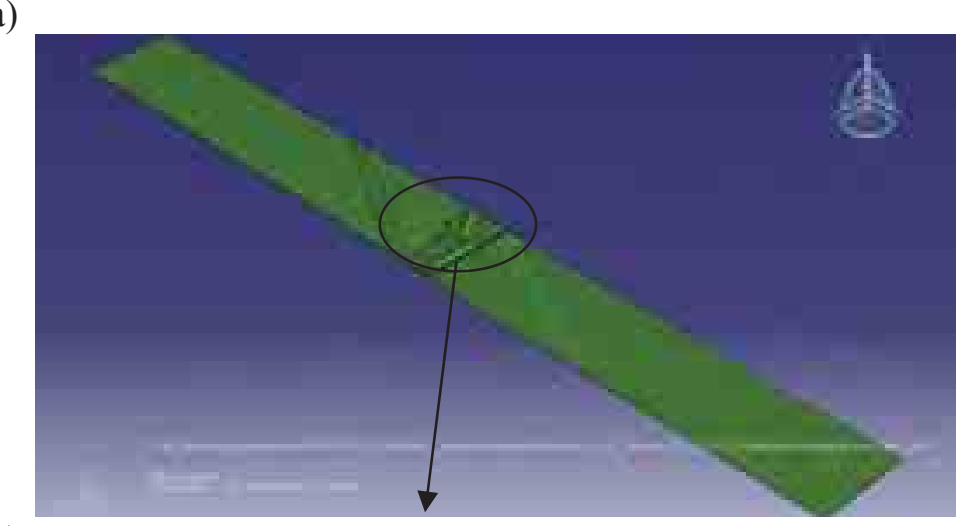

b)

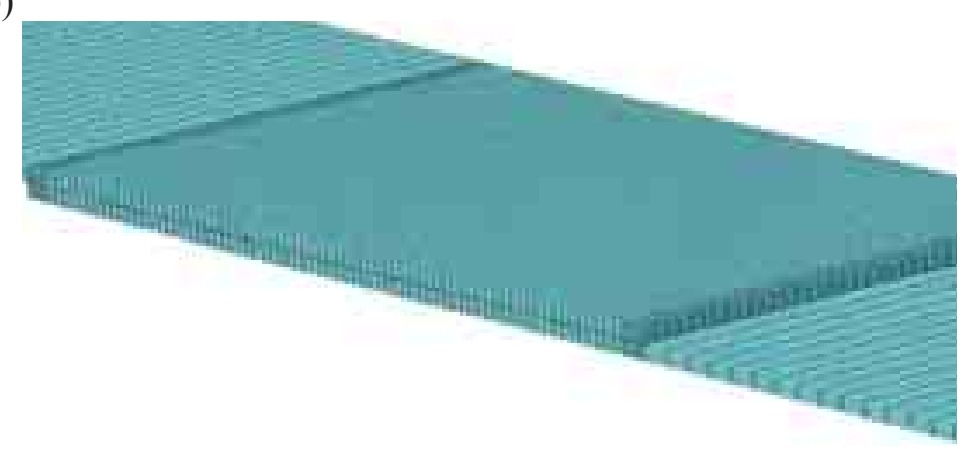

Fig. 2. Numerical model of the analysed single-lap adhesive joint: a) general view, b) view of adhesive layer [11]

Due to the non-linear properties of the analysed material joints, elastic and plastic models of both adhesive and adhered sheets were used. The non-linear geometrical character of the calculations was achieved owing to the use of incremental-iterative calculation methods based on the Newton-Raphson method.

The adhesive used in the test was defined as an Elastic-Traction material, which recorded failure of cohesive elements, COH3D8. Identification and visualisation of adhesive failure mechanisms was enabled through defining cohesive elements in modelling the adhesive layer [8-11]. The usage of cohesive elements in discretisation of the adhesive layer required defining the material and its failure mechanism. The model of the adhesive used in computations was defined in terms of failure initiation and evolution to the critical loss of rigidity and based on a TractionSeparation description presented in Fig. 3. 


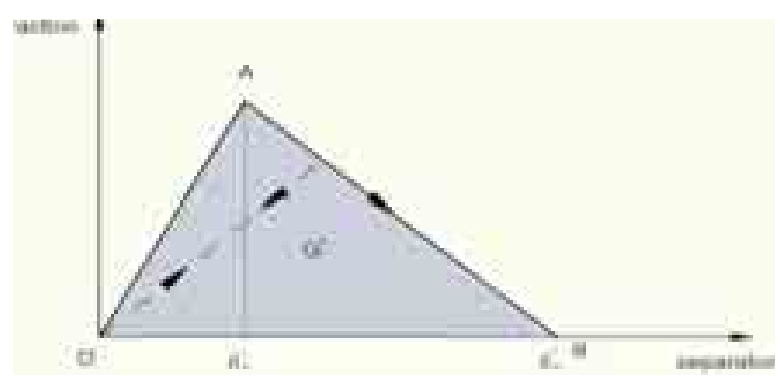

Fig. 3. Adhesive layer failure criterion description [8, 11]

Boundary conditions of the numerical model were defined by blocking the translational degree of freedom of nodes located on the front surface of the upper sheet and allowing for displacement of the front surface of the lower sheet only in the load application direction.

\section{Test results}

\subsection{Experimental tests results}

Table 1 contains destructive force values results obtained in experimental tests. It is the average value of 10 measurements.

Tab. 1. Experimental tests results

\begin{tabular}{|c|c|c|}
\hline $\begin{array}{c}\text { Failure force } \\
{[\mathrm{N}]}\end{array}$ & $\begin{array}{c}\text { Standard aberration } \\
{[\mathrm{N}]}\end{array}$ & $\begin{array}{c}\text { Strength } \\
{[\mathrm{MPa}]}\end{array}$ \\
\hline 3099 & 393 & 15.5 \\
\hline
\end{tabular}

The obtained value of the destructive force for the analysed hot dip zinc coated sheet and titanium sheet adhesive joint was used in load modelling in the numerical model of a joint.

\subsection{Numerical analysis results}

Based on the performed numerical analysis, adhesive layer destructive load value and stress distribution were obtained. Reduced stresses, determined using the Huber-Mises-Hencky strength hypothesis, were analysed. The value of the destructive force obtained using numerical analysis equalled $2410 \mathrm{~N}$.

An example of reduced stress distribution in the lap area is presented in Fig. 4, where, except for stress distribution, one of the stages of adhesive layer failure is presented in order to visualise this process in the analysed adhesive joint.

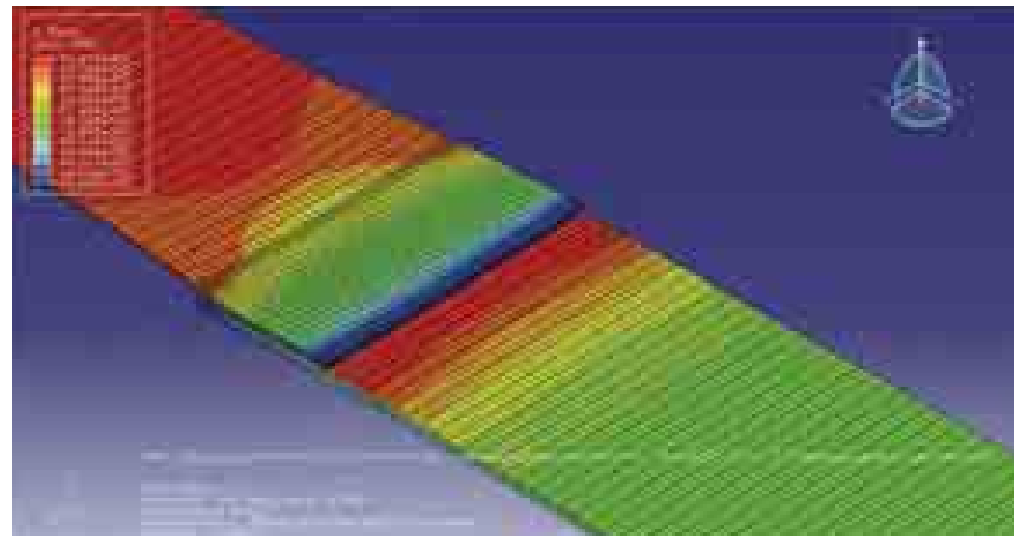

Fig. 4. Visualisation of the analysed single-lap joint failure process 
Based on numerical analysis it is possible to determine the place and the value of the force at which joint failure is initialised as well as to observe particular stages of the failure process (Fig. 5).

a)
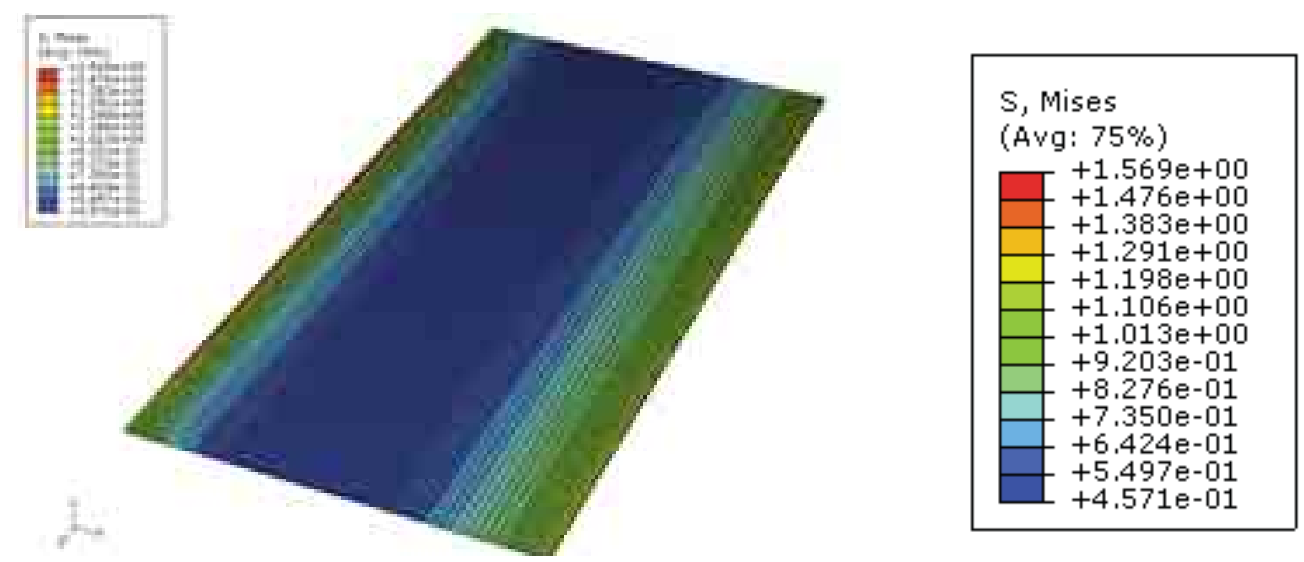

b)
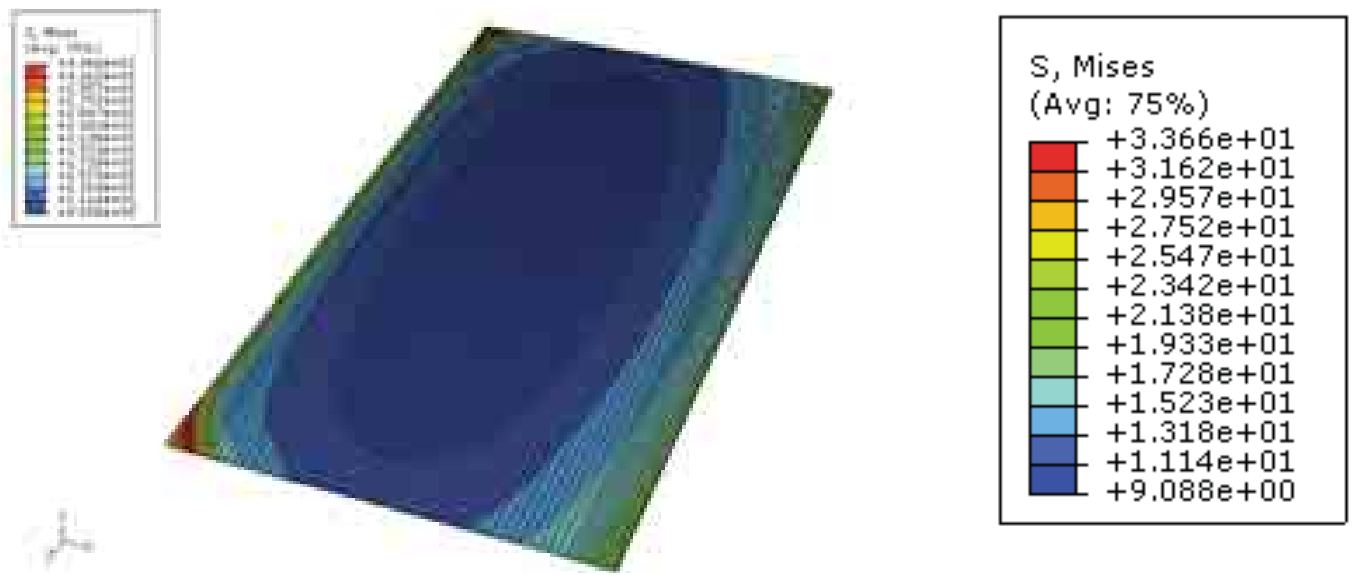

c)
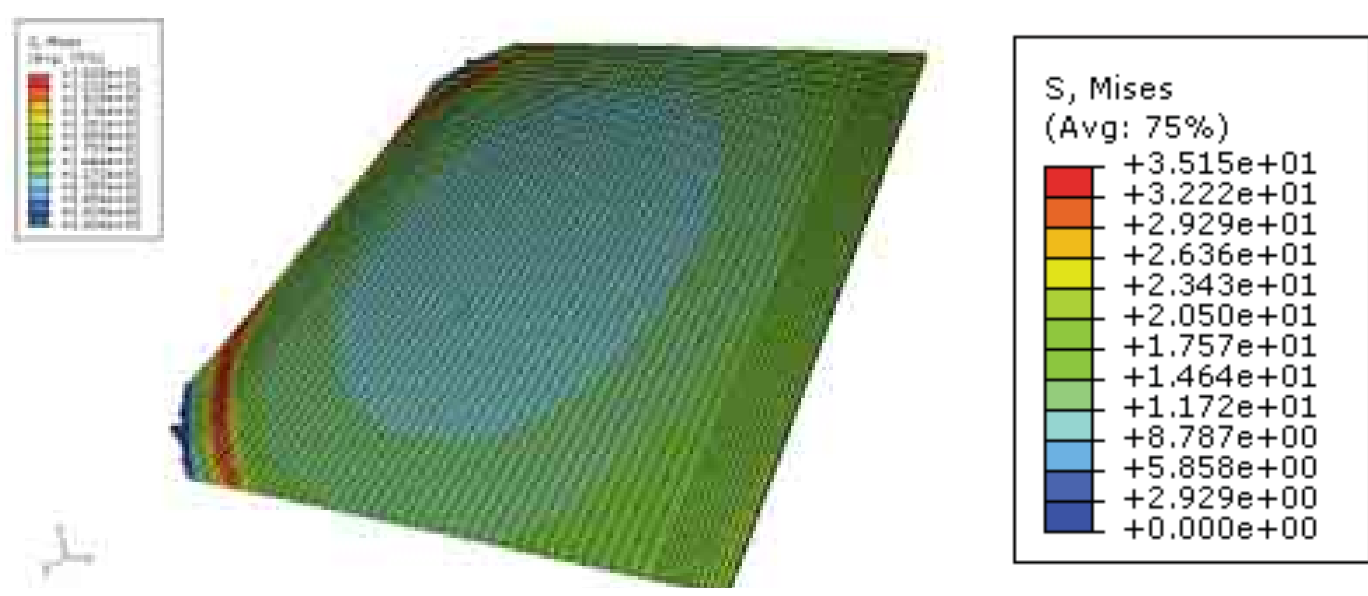

Fig. 5. Visualisation of adhesive joint failure stages of adhesive layer: a) exerting adhesive layer before the initiation of failure, b) initiation stage of failure, c) propagation of joint failure

In the analysed joint, the force value at which joint failure was initialised equalled $1541 \mathrm{~N}$. This was about $60 \%$ of failure force value. At any value higher than that, advancing degradation of rigidity of the adhesive layer successive elements to its full degradation could be observed. 


\subsection{Comparative analysis of test results}

Comparative analysis of experimental and numerical test results is presented in Tab. 2.

Tab. 2. Failure force values in experimental tests and in numerical analysis of the analysed single-lap joints

\begin{tabular}{|c|c|c|}
\hline \multirow{2}{*}{ Adhesive joint type } & \multicolumn{2}{|c|}{ Failure force value } \\
& \multicolumn{2}{|c|}{$[\mathrm{N}]$} \\
\cline { 2 - 3 } & experimental tests & Numerical analysis \\
\hline $\begin{array}{c}\text { Hot dip zinc coated sheet and CP1 } \\
\text { titanium sheet }\end{array}$ & 3099 & 2410 \\
\hline
\end{tabular}

Comparative analysis of experimental and numerical tests results showed a difference between the destructive load value obtained in experimental tests $\mathrm{P}=3099 \mathrm{~N}$ and numerical analysis $\mathrm{P}=2410 \mathrm{~N}$. The obtained agreement equalled $77.8 \%$. The dissimilarity in destructive load values may result from the hybrid nature of the joint, as not only material properties of the joined sheets but also their geometric properties (different thickness of sheets) are different. That, in turn, influences rigidity of the adhesive joint. In corresponding analyses of adhesive joints created with sheets of identical parameters, the obtained agreement exceeded $90 \%$, which proves that modelling and creating numerical models are appropriate.

\section{Conclusions/Summary}

Numerous advantages of numerical analysis contribute to its increasing popularity among engineers and frequent application at the designing stage of different structures, including adhesive joints. Nevertheless, in order for the numerical analysis to be accurate, reliable material properties data must be obtained, hence the necessity for conducting experimental tests, and frequently destructive tests.

The destructive force value obtained in the experimental tests of single-lap adhesive joints was applied in numerical analysis and allowed to obtain stress distribution pattern, determine failure initiation point and location, all of which provide invaluable information for designing and operation of such joints.

Comparative analysis of experimental and numerical tests results shows certain discrepancy between the destructive loads values obtained in the tests. The difference amounts to $22.2 \%$ and may provide information on e.g. the compatibility between the numerical model and the analysed adhesive joint. On the other hand, the discrepancy may result from an approximate character of the finite element method and the reflection of actual conditions. Nonetheless, it appears that the application of this method in the analysis of adhesive joints brings numerous benefits of significant influence on the process of designing, production and working of adhesive joints.

\section{Acknowledgements}

This scientific study was a part of a research project no. N N507 592538, financed by Ministry of Science and Higher Education.

\section{References}

[1] Abaqus 6.9, Documentation, 2009.

[2] Abaqus/Standard User's Manual version 6.5, Hibbit, Karlsson \& Sorensen, Inc., 2005.

[3] Czaplicki, J., Ćwikliński, J., Godzimirski, J., Konar, P., Klejenie tworzyw konstrukcyjnych, WKŁ, Warszawa 1987. 
[4] Godzimirski, J., Wytrzymałość doraźna konstrukcyjnych połaczeń klejowych, Wyd. WNT, Warszawa 2002.

[5] Godzimirski, J., Kozakiewicz, J., Łunarski, J., Zielecki, W., Konstrukcyjne połaczenia klejowe elementów metalowych w budowie maszyn, Oficyna Wydawnicza Politechniki Rzeszowskiej, Rzeszów 1997.

[6] Goglio, L., Rossetto, M., Dragoni, E., Design of adhesive joint based on peak elastic stresses, International Journal of Adhesion and Adhesives, 28, pp. 427-435, 2008.

[7] Grant, L. D. R., Adams, R. D., da Silva, L. F. M., Effect of the temperature on the strength of adhesively bonded single lap and $T$ joints for the automotive industry, International Journal of Adhesion and Adhesives, 29, pp. 535-542, 2009.

[8] Moura, M. F. S. F., Concalves, J. P. M., Chousal, J. A. G., Campilho, R. D. S. G., Cohesive and continuum mixed-mode damage models applied to the simulation of the mechanical behavior of bonded joints, International Journal of Adhesion and Adhesives, 28, pp. 419-426, 2008.

[9] Rudawska, A., Dębski, H., Ocena wytrzymałości połaczeń klejowych blach ze stopu aluminium z wykorzystaniem analizy numerycznej MES, Eksploatacja i Niezawodność, No. 1, pp. 4-10, 2011.

[10] Rudawska, A., Dębski, H., Modelowanie procesu zniszczenia spoiny klejowej w jednozakładkowym połaczeniu klejowym blach aluminiowych, Mechanik, Nr 2, pp. 118-121, 2010.

[11] Rudawska, A., Adhesive joint strength of hybrid assemblies: Titanium sheet-composites and aluminium sheet-composites-Experimental and numerical verification, International Journal of Adhesion and Adhesives, 29, pp. 451-457, 2010.

[12] Rusiński, E., Czmochowski, J., Smolnicki, T., Zaawansowana metoda elementów skończonych w konstrukcjach nośnych, Oficyna Wydawnicza Politechniki Wrocławskiej, Wrocław 2000.

[13] da Silva, L. F. M., Adams, R. D., Techniques to reduce the peel stresses in adhesive joints with composites, International Journal of Adhesion and Adhesives, 27, pp. 227-235, 2007.

[14] Taib, A. A., Boukhili, R., Achiou, S., Gordon, S., Boukehili, H., Bonded joints with composite adherends. Part I. Effect of specimen configuration, adhesive thickness, spew fillet and adherend stiffness on fracture. International Journal of Adhesion and Adhesives, 26, pp. 226-236, 2006.

[15] Wang, J., Zhang, Ch., Three-parameter, elastic foundation model for analysis of adhesively bonded joints, International Journal of Adhesion and Adhesives, 29, pp. 495-502, 2009.

[16] You, M., Yan, Z.-M., Zheng, X.-.L, Yu, H.-.Z, Li, Z., A numerical and experimental study of gap length on adhesively bonded aluminium double-lap joint, International Journal of Adhesion and Adhesives, 27, pp. 696-702, 2007. 